\title{
Cultivar Sensitivity to Ethylene During Storage and 1-Methylcyclopropene Protection of Aglaonema
}

\author{
Shu-Ting Fan, Der-Ming Yeh ${ }^{1}$, and Tsu-Tsuen Wang \\ Department of Horticulture, National Taiwan University, No. 1, Roosevelt \\ Road Section 4, Taipei, Taiwan 106
}

Additional index words. Aglaonema, chlorophyll fluorescence, potted foliage plants, SPAD502 value, 1-methylcyclopropene

\begin{abstract}
This study determined the sensitivity of two Aglaonema cultivars to ethylene and evaluated the effectiveness of 1-methylcyclopropene (1-MCP) to protect sensitive cultivars. Plants of 'White Tip' and 'Chalit's Fantasy' were exposed to various ethylene concentrations for 7 days during dark storage at $15^{\circ} \mathrm{C}$. Poststorage performance, measured as number of chlorotic leaves and quality rating, was recorded after the plants were placed in the indoor environments for 14 days. Exposure to $4.5 \mu L \cdot L^{-1}$ ethylene resulted in increased chlorotic leaves and reduced quality rating in 'White Tip' but did not affect poststorage performance in 'Chalit's Fantasy'. Exposure to $4.5 \mu \mathrm{L} \cdot \mathrm{L}^{-1}$ ethylene reduced both the soil plant analytical development-502 (SPAD-502) and variable fluorescence/maximal fluorescence $(\mathrm{Fv} / \mathrm{Fm})$ values of the lowest leaves in 'White Tip' but not in 'Chalit's Fantasy'. Chlorotic leaf number increased; the SPAD-502 value, Fv/Fm, and Fm of the lowest leaves decreased in 'White Tip' as ethylene concentration increased from 0 to $4.1 \mu \mathrm{L} \cdot \mathrm{L}^{-1}$. Plants of 'White Tip' pretreated with $300 \mathrm{or} 900 \mathrm{~nL} \cdot \mathrm{L}^{-1} 1$ MCP for $6 \mathrm{~h}$ had fewer chlorotic leaves, higher Fv/Fm, and SPAD-502 values and better postproduction quality than those without 1-MCP pretreatment in response to treatment with $1.1 \mu \mathbf{L} \cdot \mathbf{L}^{-1}$ ethylene during storage.
\end{abstract}

The interest in interior plantscape has increased the development of international markets for tropical foliage plants. The prime goal for shippers and wholesalers is to deliver plants with minimum quality deterioration. Foliage plants are not particularly heavy ethylene producers (Blessington and Collins, 1993). However, ethylene can be found within foliage plant shipping containers as mixed loads with fruits or vegetables, which release significant amounts during the ripening process (Conover and Poole, 1987). Exposure to ethylene at $0.1 \mu \mathrm{L} \cdot \mathrm{L}^{-1}$ or higher concentrations during storage would reduce postproduction quality in certain foliage plants (Blessington and Collins, 1993; Leonard et al., 2008).

Ethylene can cause leaf abscission and/or chlorosis in various foliage plant species (Blessington and Collins, 1993; Marousky and Harbaugh, 1979; Wang and Dunlap, 1990; Woltering, 1987). Beneficial effects of using 1-methylcyclopropene (1-MCP) have been shown to protect many cut flowers (Serek et al., 1995) and potted foliage plants (Leonard et al., 2008) against ethylene. It has been documented that only very low concentrations of $1-\mathrm{MCP}$, in the range of $2.5 \mathrm{~nL} \cdot \mathrm{L}^{-1}$ to $1 \mu \mathrm{L} \cdot \mathrm{L}^{-1}$, are sufficient for preventing ethylene response (Blankenship and Dole, 2003; Serek et al., 1995).

Received for publication 18 Aug. 2008. Accepted for publication 23 Oct. 2008.

${ }^{1}$ To whom reprint requests should be addressed; e-maildmyeh@ntu.edu.tw.
Ethylene could decrease leaf chlorophyll concentration and cause leaf yellowing (Koukounaras et al., 2006). The soil plant analytical development (SPAD) chlorophyll meter is often used to measure relative concentration of chlorophyll and thus may provide in situ and rapid evaluation of ethylene sensitivity. Chlorophyll degradation is typically associated with photosynthetic efficiency of open reaction centers of photosystem II (PS II) (DeEll et al., 1999). Chlorophyll fluorescence is an intriguing tool that can assess photosynthetic performance and monitor plant response to the environmental stress (Adams and DemmigAdams, 2004). The Fv/Fm (potential photochemical efficiency of PS II) is typically in the range of 0.75 to 0.85 for nonstressed plants (Bolhar-Nordenkampf et al., 1989). Chlorophyll fluorescence has potential for rapid quantitative assessment of ethylene injury in leaves.

Aglaonema is one of the most popular foliage plant genera as a result of its attractive foliar variegation and tolerance to drought and low light conditions. Injury resulting from ethylene is generally not a problem when plants of Aglaonema spp. are shipped within the recommended temperatures between 13 and $18^{\circ} \mathrm{C}$ (Blessington and Collins, 1993). However, Leonard et al. (2008) showed that treatment of Aglaonema sp. 'Mary Anne' plants with $10 \mu \mathrm{L} \cdot \mathrm{L}^{-1}$ ethylene caused leaf chlorosis. It was probable that differential cultivar sensitivity to ethylene existed in Aglaonema. The aim of the present work was to compare ethylene sensitivity of
Aglaonema cultivars and determine the effect of 1-MCP pretreatments on poststorage performance in the ethylene-sensitive cultivar. We investigated whether measurements of poststorage SPAD and chlorophyll fluorescence could provide rapid and simple methods for assessing ethylene injury and 1-MCP protection.

\section{Materials and Methods}

Three experiments were conducted in this study. Plants were all purchased from a commercial production area under a $60 \%$ shaded greenhouse with an average noontime photosynthetic photon flux $(P P F)$ of $350 \mu \mathrm{mol} \cdot \mathrm{m}^{-2} \cdot \mathrm{s}^{-1}$ and growing temperatures of 18 to $30{ }^{\circ} \mathrm{C}$. Plants were planted in $18-\mathrm{cm}$ diameter plastic pots containing a coir-based medium commonly used for commercial production of Araceae plants. When the plants were treated with ethylene, sufficient ethylene was injected into sealed polypropylene boxes to provide a range of treatment concentrations for $7 \mathrm{~d}$ at $15{ }^{\circ} \mathrm{C}$ in a dark room. Gas samples of $1 \mathrm{~mL}$ were withdrawn with a syringe from the storage boxes every $12 \mathrm{~h}$ during storage to monitor ethylene concentration. When ethylene concentration was $0.1 \mu \mathrm{L} \cdot \mathrm{L}^{-1}$ lower than the needed treatment concentration, sufficient ethylene was injected into the boxes again. Ethylene concentration in the air samples was measured by a gas chromatograph (GC 14-A; Shimadzu, Tokyo, Japan) equipped with a Porapack Q column (80/100 mesh) and a flame ionization detector. After ethylene treatments, plants were placed under indoor environments at $23 \pm 3{ }^{\circ} \mathrm{C}, 70 \%$ to $80 \%$ relative humidity, with a 12-h photoperiod from warm-white fluorescent tubes providing 9 to $14 \mu \mathrm{mol} \cdot \mathrm{m}^{-2} \cdot \mathrm{s}^{-1} \mathrm{PPF}$ at the top of the plant canopy.

Number of chlorotic leaves and quality rating $(1=$ poor, not salable; $3=$ good, salable; and $5=$ excellent quality) were recorded after $14 \mathrm{~d}$ indoors in each treatment. The lowest leaf from each plant was sampled for measuring relative chlorophyll concentration and chlorophyll fluorescence. Relative chlorophyll concentration was measured in situ with a chlorophyll meter (SPAD502; Minolta Camera Co., Tokyo, Japan). Minimal fluorescence (Fo) was determined after 30 min dark adaptation at $25{ }^{\circ} \mathrm{C}$, whereas maximal fluorescence $(\mathrm{Fm})$ was measured after a saturation pulse with a modulatedlight MiniPam (Heinz Walz GmbH, Effeltrich, Germany). The fluorescence ratio $\mathrm{Fv} /$ $\mathrm{Fm}$, with $\mathrm{Fv}=\mathrm{Fm}-\mathrm{Fo}$ being the variable fluorescence, was then calculated.

Expt. 1: Aglaonema. 'White Tip' and 'Chalit's Fantasy' were chosen because these cultivars have been widely grown and exported overseas. Plants with $23 \pm 3$ fully expanded leaves were used. On 2 Mar. 2006, a group of five plants (unstored control) were placed directly indoors, whereas other groups of five plants were placed in the boxes that contained 0 or $4.5 \mu \mathrm{L} \cdot \mathrm{L}^{-1}$ ethylene and then transferred indoors. Measurements of 
Table 1. Effects of ethylene concentration and storage duration at $15^{\circ} \mathrm{C}$ on subsequent number of chlorotic leaves and quality rating in Aglaonema cultivars White Tip and Chalit's Fantasy at Day 14 in the simulated indoor environments. ${ }^{z}$

\begin{tabular}{|c|c|c|c|c|c|}
\hline \multirow[b]{2}{*}{$\mathrm{C}_{2} \mathrm{H}_{4}\left(\mu \mathrm{L} \cdot \mathrm{L}^{-1}\right)$} & \multirow[b]{2}{*}{$\begin{array}{c}\text { Storage } \\
\text { duration (d) }\end{array}$} & \multicolumn{2}{|c|}{ White Tip } & \multicolumn{2}{|c|}{ Chalit's Fantasy } \\
\hline & & $\begin{array}{c}\text { Number of } \\
\text { chlorotic leaves }\end{array}$ & $\begin{array}{l}\text { Quality } \\
\text { rating }^{y}\end{array}$ & $\begin{array}{c}\text { Number of } \\
\text { chlorotic leaves }\end{array}$ & $\begin{array}{l}\text { Quality } \\
\text { rating }\end{array}$ \\
\hline 0 & 0 & $0.0 \mathrm{~b}^{\mathrm{x}}$ & $5.0 \mathrm{a}$ & $0.0 \mathrm{a}$ & $5.0 \mathrm{a}$ \\
\hline 0 & 7 & $0.0 \mathrm{~b}$ & $5.0 \mathrm{a}$ & $0.0 \mathrm{a}$ & $5.0 \mathrm{a}$ \\
\hline 4.5 & 7 & $10.6 \mathrm{a}$ & $1.8 \mathrm{~b}$ & $0.0 \mathrm{a}$ & $5.0 \mathrm{a}$ \\
\hline
\end{tabular}

${ }^{2}$ Unstored control plants were not exposed to ethylene (Expt. 1).

${ }^{\mathrm{y}}$ Quality rating: 1 = poor, not salable; 3 = good, salable; 5 = excellent quality.

${ }^{x}$ Mean separation in columns by least significant difference test at $P \leq 0.05$.

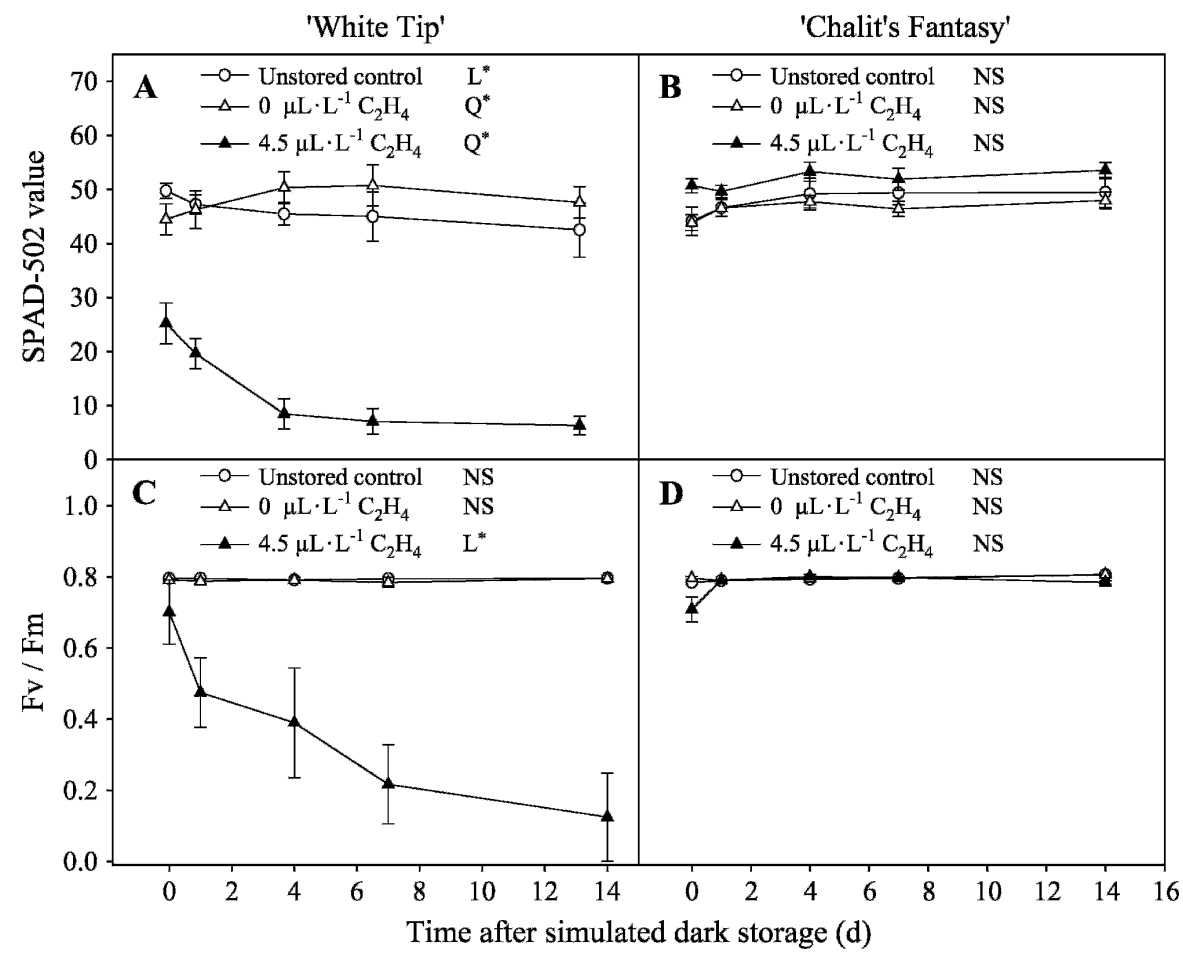

Fig. 1. Changes in SPAD-502 value and Fv/Fm in the lowest leaves of Aglaonema 'White Tip' and 'Chalit's Fantasy' during $14 \mathrm{~d}$ in the simulated indoor environments after storage at $15{ }^{\circ} \mathrm{C}$ for $7 \mathrm{~d}$ with 0 or $4.5 \mu \mathrm{L} \cdot \mathrm{L}^{-1}$ ethylene. Unstored control plants were not exposed to ethylene. Bars represent SE of the mean; $\mathrm{n}=5$ (Expt. 1). SPAD = soil plant analytical development; $\mathrm{Fv} / \mathrm{Fm}=$ variable fluorescence/ maximal fluorescence.

Table 2. Effects of ethylene concentration during storage at $15{ }^{\circ} \mathrm{C}$ for $7 \mathrm{~d}$ on subsequent number of chlorotic leaves and quality rating in Aglaonema 'White Tip' at Day 14 in the simulated indoor environments. ${ }^{\mathrm{z}}$

\begin{tabular}{lccc}
\hline $\mathrm{C}_{2} \mathrm{H}_{4}$ during storage $\left(\mu \mathrm{L} \cdot \mathrm{L}^{-1}\right)$ & Storage duration $(\mathrm{d})$ & Number of chlorotic leaves & Quality rating $^{\mathrm{y}}$ \\
\hline 0 & 0 & 0.2 & 4.8 \\
0 & 7 & 3.0 & 3.8 \\
0.8 & 7 & 6.2 & 3.0 \\
2.6 & 7 & 7.8 & 2.4 \\
4.1 & 7 & 10.8 & 2.2 \\
Unstored control & & & $*$ \\
$\quad$ versus storage & & $\mathrm{L}$ & \\
$\mathrm{C}_{2} \mathrm{H}_{4}$ concentration & & & $\mathrm{L}$ \\
\hline
\end{tabular}

${ }^{\mathrm{z}}$ Unstored control plants were not exposed to ethylene (Expt. 2).

${ }^{\mathrm{y}}$ Quality rating: $1=$ poor, not salable; $3=$ good, salable; and $5=$ excellent quality.

${ }^{*, * *, * * *}$ Significant at $P \leq 0.05,0.01$, or 0.001 , respectively; $\mathrm{L}=$ linear; $\mathrm{Q}=$ quadratic.

SPAD-502 value, Fv/Fm, and/or Fm were taken at Days $0,1,4,7$, and 14 after storage.

Expt. 2: Aglaonema. 'White Tip' appeared to be sensitive to ethylene during storage like results achieved in Expt. 1. Thus, we carried out Expt. 2 to examine more details in the ethylene concentration effects on poststorage performance, relative chlorophyll concentration, and chlorophyll fluorescence. Uniform plants of 'White Tip' with $45 \pm 7$ fully expanded leaves were used. On 15 Dec. 2006, a group of six plants (unstored control) were placed directly indoors. Other groups of six plants were placed in the boxes that contained $0,0.8,2.6$, or $4.1 \mu \mathrm{L} \cdot \mathrm{L}^{-1}$ ethylene and then transferred indoors. Measurements of SPAD-502 value, Fv/Fm, and Fm were taken at Days 0, 1, 4, 7, and 14 after storage.

Expt. 3. The experiment was designed to explore possible 1-MCP protection for ethylene injury in 'White Tip'. Uniform plants of Aglaonema 'White Tip' with $33 \pm 3$ fully expanded leaves were used. The experiment was conducted from 9 Apr. to 1 May 2007. A group of six plants (unstored control) was placed indoors. Other groups of six plants were pretreated with 0,300 , or $900 \mathrm{~nL} \cdot \mathrm{L}^{-1}$ $1-\mathrm{MCP}$ at $20^{\circ} \mathrm{C}$ in sealed boxes for $6 \mathrm{~h}$ and then stored at $15{ }^{\circ} \mathrm{C}$ for $7 \mathrm{~d}$ with $1.1 \mu \mathrm{L} \cdot \mathrm{L}^{-1}$ ethylene, which could be detected in our shipping environments. After storage, plants were transferred indoors. 1-MCP was applied using EthylBloc (Biotechnologies for Horticulture Inc., Walterboro, SC) following the directions for use. Measurements of SPAD502 value and $\mathrm{Fv} / \mathrm{Fm}$ were taken at Days 0,1 , 4,7 , and 14 after storage.

All these experiments were arranged in a completely randomized design. Linear and quadratic regression analyses were performed and presented using Sigma Plot 8.0 programming (SPSS, Chicago, IL). Least significant differences were determined at $P \leq 0.05$ to compare means.

\section{Results and Discussion}

In Expt. 1, no chlorotic leaf was observed in unstored control plants and those stored for $7 \mathrm{~d}$ without exposure to ethylene in both cultivars (Table 1). Exposure to $4.5 \mu \mathrm{L} \cdot \mathrm{L}^{-1}$ ethylene reduced poststorage performance of 'White Tip', whereas 'Chalit's Fantasy' did not exhibit chlorotic leaves and remained excellent quality. Differential cultivar response to ethylene was reported for cut flower crops (Wu et al., 1991) and potted flowering plants (Serek and Reid, 2000), but not for foliage plants. The present study showed that ethylene sensitivity varied between Aglaonema cultivars.

In 'White Tip', unstored control or plants stored without ethylene treatment maintained SPAD-502 values between 40 and 50 in the indoor environments for $14 \mathrm{~d}$, whereas plants stored with $4.5 \mu \mathrm{L} \cdot \mathrm{L}^{-1}$ ethylene exhibited reduction in SPAD-502 value from 25 to 8 (Fig. 1A). Similar ethylene injury symptom expressed as leaf yellowing was reported for other potted foliage plants, including Dieffenbachia maculata G. Don 'Marianne', Dracaena marginata Lam., Dracaena sanderiana Hort. Sander ex M. T. Mast., and Yucca elephantipes Regel. (Woltering, 1986, 1987). Exposure to ethylene caused chlorosis only on the basal oldest leaves in 'White Tip'. Onozaki et al. (2004) reported that ethylene sensitivity differs in different ages of the plant organ. In contrast, storage with $4.5 \mu \mathrm{L} \cdot \mathrm{L}^{-1}$ ethylene did not reduce poststorage SPAD-502 value in 'Chalit's Fantasy' (Fig. 1B). A similar result was reported for 


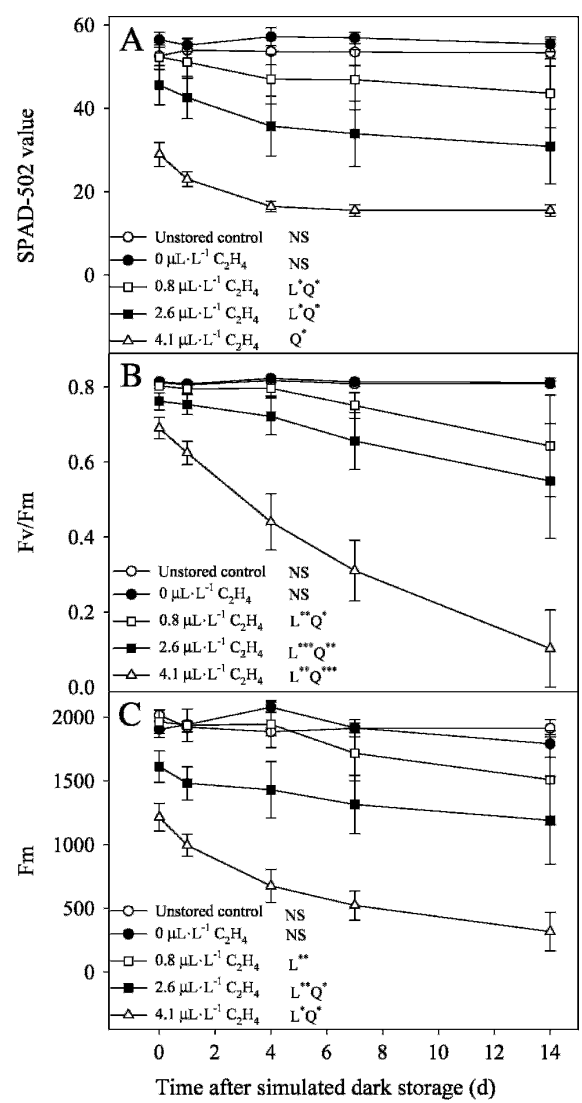

Fig. 2. Changes in SPAD-502 value (A), Fv/Fm (B), and Fm (C) of the lowest leaves in Aglaonema 'White Tip' during $14 \mathrm{~d}$ in the simulated indoor environments after storage at $15{ }^{\circ} \mathrm{C}$ for $7 \mathrm{~d}$ with $0,0.8,2.6$, or $4.1 \mu \mathrm{L} \cdot \mathrm{L}^{-1}$ ethylene. Unstored control plants were not exposed to ethylene. Bars represent SE of the mean; $\mathrm{n}=6$ (Expt. 2). SPAD $=$ soil plant analytical development; $\mathrm{Fv} / \mathrm{Fm}$ = variable fluorescence/maximal fluorescence.

Table 3. Effects of 1-MCP concentration on number of chlorotic leaves and quality rating in Aglaonema 'White Tip' at Day 14 in the simulated indoor environments. ${ }^{\mathrm{z}}$

\begin{tabular}{lccc}
\hline $\begin{array}{l}\text { 1-MCP } \\
\left(\mathrm{nL} \cdot \mathrm{L}^{-1}\right)\end{array}$ & $\begin{array}{c}\mathrm{C}_{2} \mathrm{H}_{4} \\
\left(\mu \mathrm{L} \cdot \mathrm{L}^{-1}\right)\end{array}$ & $\begin{array}{c}\text { Number of } \\
\text { chlorotic } \\
\text { leaves }\end{array}$ & $\begin{array}{c}\text { Quality } \\
\text { rating }\end{array}$ \\
\hline 0 & 0 & 0.7 & 4.3 \\
0 & 1.1 & 3.8 & 2.5 \\
300 & 1.1 & 0.7 & 4.3 \\
900 & 1.1 & 0.5 & 4.5 \\
Significance & & & \\
$\begin{array}{l}\text { Least } \\
\quad \text { significant }\end{array}$ & & 2.14 & 1.06 \\
$\quad$ difference & & & \\
at $P=0.05$ & & & \\
1-MCP & & $\mathrm{L}^{*} \mathrm{Q}^{*}$ & $\mathrm{~L} * * \mathrm{Q}^{* *}$ \\
$\quad$ concentration & & & \\
\hline
\end{tabular}

${ }^{\text {zPlants were pretreated with } 0,300 \text {, or } 900 \mathrm{~nL} \cdot \mathrm{L}^{-1}}$ 1-MCP for $6 \mathrm{~h}$ followed by storage at $15^{\circ} \mathrm{C}$ for $7 \mathrm{~d}$ with $1.1 \mu \mathrm{L} \cdot \mathrm{L}^{-1}$ ethylene. Unstored control plants were not exposed to ethylene (Expt. 3).

${ }^{y}$ Quality rating: 1 = poor, not salable; 3 = good, salable; $5=$ excellent quality.

${ }^{*},{ }^{* *}$ Significant at $P \leq 0.05$, or 0.01 respectively; $\mathrm{L}=$ linear; $\mathrm{Q}=$ quadratic .

$1-\mathrm{MCP}=1$-methylcyclopropene. chrysanthemum in that ethylene accelerated the rate of chlorophyll loss in detached leaves of 'Tara' but had no effect on 'Boaldi' (Reyes-Arribas et al., 2001). This nondestructive, in situ chlorophyll meter could aid in monitoring leaf chlorophyll status of Aglaonema after storage.

For 'White Tip', unstored control and stored plants without ethylene treatment maintained $\mathrm{Fv} / \mathrm{Fm}$ values $\approx 0.8$ during 14 $\mathrm{d}$ indoor conditions, whereas plants treated with $4.5 \mu \mathrm{L} \cdot \mathrm{L}^{-1}$ ethylene exhibited reduction in $\mathrm{Fv} / \mathrm{Fm}$ values from 0.7 to 0.1 (Fig. 1C). Fv/ Fm represents the maximum efficiency of PS II in transforming light energy to chemical energy and the integrity of the reaction center and light harvesting complex of PS II (DeEll et al., 1999). The decrease in Fv/Fm accompanied by lower SPAD values in 'White Tip' might be the result of the degradation of chlorophyll and the failure to maintain efficient of PS II. In contrast, the $\mathrm{Fv} / \mathrm{Fm}$ of 'Chalit's Fantasy' in unstored control and those stored with $4.5 \mu \mathrm{L} \cdot \mathrm{L}^{-1}$ ethylene maintained between 0.7 and 0.8 , within the range from 0.75 to 0.85 for nonstress plants (Bolhar-Nordenkampf et al., 1989). Measurements of $\mathrm{Fv} / \mathrm{Fm}$ during poststorage could provide a nondestructive, rapid method to detect ethylene injury before visible symptoms of chlorotic leaves appear in Aglaonema plants. Differential ethylene sensitivity in carnation cultivars could be partially explained by differences in ethylene-binding activity in petal tissues (Wu et al., 1991). It would be of interest to examine the ethylene responses in leaves at the receptor level that could affect PS II of Aglaonema 'White Tip' and 'Chalit's Fantasy'.

In Expt. 2, plants of 'White Tip' exposed to a low concentration of $0.8 \mu \mathrm{L} \cdot \mathrm{L}^{-1}$ ethylene had more chlorotic leaves than did those unstored control and stored plants without ethylene treatment (Table 2). Number of chlorotic leaves increased and quality rating decreased with increasing ethylene concentration from 0 to $4.1 \mu \mathrm{L} \cdot \mathrm{L}^{-1}$. Høyer (1996) also reported that the abscission of buds and leaves of Hibiscus rosa-sinensis L. depended on ethylene concentration and duration of exposure.

In 'White Tip', the unstored control plants and those stored without exposure to ethylene maintained SPAD-502 values between 50 and 60 under indoor conditions for $14 \mathrm{~d}$ (Fig. 2A). Poststorage SPAD-502 value decreased with increasing ethylene concentration during storage. The changes in $\mathrm{Fv} / \mathrm{Fm}$ (Fig. 2B) and Fm (Fig. 2C) during 14-d indoor conditions were similar to SPAD-502 value as described. Clearly, ethylene during storage damaged PS II in 'White Tip' as shown by decreases in $\mathrm{Fv} / \mathrm{Fm}$ and $\mathrm{Fm}$ values. $\mathrm{Fm}$ is achieved only after complete $\mathrm{Q}_{\mathrm{A}}$ reduction and exclusion of all other quenching mechanisms (DeEll et al., 1999). Decreased hydrolysis activity may result in lower leaf Fm values (Mohanty et al., 1989).

In Expt. 3, plants of 'White Tip' exposed to $1.1 \mu \mathrm{L} \cdot \mathrm{L}^{-1}$ ethylene without 1 -MCP pretreatment had more chlorotic leaves and

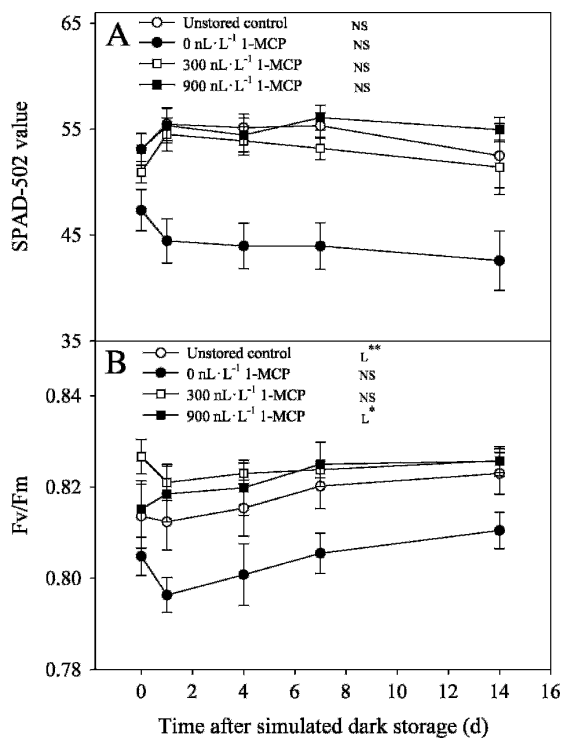

Fig. 3. Changes in the SPAD-502 value (A) and Fv/ Fm (B) of the lowest leaves in Aglaonema 'White Tip' during $14 \mathrm{~d}$ in the simulated indoor environments. Plants were pretreated with 0 , 300 , or $900 \mathrm{n} \mathrm{L} \cdot \mathrm{L}^{-1} 1$-methylcyclopropene for $6 \mathrm{~h}$ followed by storage at $15^{\circ} \mathrm{C}$ for $7 \mathrm{~d}$ with $1.1 \mu \mathrm{L} \cdot \mathrm{L}^{-1}$ ethylene. Unstored control plants were not exposed to ethylene. Bars represent SE of the mean; $n=6$ (Expt. 3). SPAD $=$ soil plant analytical development; Fv/Fm = variable fluorescence/maximal fluorescence.

lower quality rating (Table 3 ). The unstored control and plants pretreated with 300 or $900 \mathrm{~nL} \cdot \mathrm{L}^{-1} 1-\mathrm{MCP}$ had similar poststorage performance. Leonard et al. (2008) have also shown that pretreatment of Aglaonema sp. 'Mary Anne' with $900 \mathrm{~nL} \cdot \mathrm{L}^{-1} 1-\mathrm{MCP}$ for $5 \mathrm{~h}$ at $21{ }^{\circ} \mathrm{C}$ before a $3-\mathrm{d}$ storage at $15{ }^{\circ} \mathrm{C}$ rendered plants completely insensitive to a subsequent $4-\mathrm{d}$ exposure to 1 or $10 \mu \mathrm{L} \cdot \mathrm{L}^{-1}$ ethylene. Similar effects of 1-MCP reducing chlorosis were reported for the cuttings of other foliage plants such as Epipremnum pinnatum $\mathrm{L}$. and Codiaeum variegatum var. pictum (Lobb.) Muell. 'Aucubaefolia' (Müller et al., 1997, 1998). Poststorage performance, SPAD-502 value, and Fv/Fm did not differ in 'White Tip' pretreated with 300 or $900 \mathrm{~nL} \cdot \mathrm{L}^{-1} 1-\mathrm{MCP}$ (Table 3; Fig. 3), suggesting that $300 \mathrm{~nL} \cdot \mathrm{L}^{-1} 1-\mathrm{MCP}$ might reach a saturated concentration. A similar result was report for parsley (Petroselinum cripum Mill.) that 10 and $50 \mu \mathrm{L} \cdot \mathrm{L}^{-1} 1-\mathrm{MCP}$ treatments did not differ in the chlorophyll levels, indicating that $10 \mu \mathrm{L} \cdot \mathrm{L}^{-1}$ was already a saturating concentration (Ella et al., 2003). The present study showed that 1-MCP pretreatment could protect Aglaonema 'White Tip' against ethylene-induced chlorophyll degradation and PS II damage. Pretreatment with $300 \mathrm{~nL} \cdot \mathrm{L}^{-1} 1-\mathrm{MCP}$ for $6 \mathrm{~h}$ could protect possible ethylene injury during storage efficiently and economically.

\section{Literature Cited}

Adams, W.W. and B. Demmig-Adams. 2004 Chlorophyll fluorescence as a tool to monitor plant response to the environment, p. 583-604. In: Papageorgiou, G.C., and X. Govindjee 
(eds.). Chlorophyll a fluorescence: Signature of photosynthesis. Springer, Dordrecht, The Netherlands.

Blankenship, S.M. and J.M. Dole. 2003. 1-Methylcyclopropene: A review. Postharvest Biol. Technol. 28:1-25.

Blessington, T.M. and P.C. Collins. 1993. Foliage plants: Prolonging quality. Ball Publishing, Batavia, IL. p. 22-24.

Bolhar-Nordenkampf, H.R., S.P. Long, N.R. Baker, G. Oquist, U. Schreiber, and E.G. Lechner. 1989. Chlorophyll fluorescence as a probe of the photosynthetic competence of leaves in the field: A review of current instrumentation. Funct. Ecol. 3:497-514.

Conover, C.A. and R.T. Poole. 1987. Factors influencing shipping of acclimatized foliage plant. Foliage Dig. 10:15-16.

DeEll, J.R., O. van Kooten, R.K. Prange, and D.P. Murr. 1999. Application of chlorophyll fluorescence techniques in postharvest physiology. Hort. Rev. (Amer. Soc. Hort. Sci.) 23:69-107.

Ella, L., A. Zion, A. Nehemia, and L. Amnon. 2003. Effect of the ethylene action inhibitor 1methylcyclopropene in parsley leaf senescence and ethylene biosynthesis. Postharvest Biol. Technol. 30:67-74.

Høyer, L. 1996. Critical ethylene exposure for Hibiscus rosa-sinensis is dependent on an interaction between ethylene concentration and duration. Postharvest Biol. Technol. 9:87-95.

Koukounaras, A., A.S. Siomos, and E. Sfakiotakis. 2006. 1-methylclopropene prevents ethylene induced yellowing of rocket leaves. Postharvest Biol. Technol. 26:339-345.

Leonard, R., A. Macnish, T. Nell, and A. Alexander. 2008. Using 1-Methylcyclopropene to prevent ethylene-induced damage on potted foliage plants. HortScience 43:1284 (Abstract)

Marousky, F.J. and B.K. Harbaugh. 1979. Interactions of ethylene, temperature, light, and $\mathrm{CO}_{2}$ on leaf and stipule abscission and chlorosis in Philodendron scandens subsp. oxycardium. J. Amer. Soc. Hort. Sci. 104:876-880.

Mohanty, N., I. Vass, and S. Demeter. 1989. Copper toxicity affects photosystem II electron transport at the secondary quinone acceptor (QB). Plant Physiol. 90:175-179.

Müller, R., M. Serek, E.C. Sisler, and A.S. Andersen. 1997. Poststorage quality and rooting ability of Epipremnum pinnatum cuttings after treatment with ethylene action inhibitors. J. Hort. Sci. 72:445-452.

Müller, R., M. Serek, E.C. Sisler, and A.S. Andersen. 1998. Ethylene involvement in leaf abscission, chlorosis, and rooting of Codiaeum variegatum var. pictum (Lodd) Muell 'Aucubaefolia'. Gartenbauwissenschaft 63:66-71.
Onozaki, T., H. Ikeda, and M. Shibata. 2004. Video evaluation of ethylene sensitivity after anthesis in carnation (Dianthus caryophyllus L.) flowers. Scientia Hort. 99:187-197.

Reyes-Arribas, T., J.E. Barrett, D.J. Huber, T.A. Nell, and D.G. Clark. 2001. Leaf senescence in a non-yellowing cultivar of chrysanthemum (Dendranthema grandiflora). Physiol. Plant. 111:540-544.

Serek, M. and M.S. Reid. 2000. Ethylene and postharvest performance of potted kalanchoe. Postharvest Biol. Technol. 18:43-48.

Serek, M., E.C. Sisler, and M.S. Reid. 1995. Effects of 1-MCP on the vase life and ethylene response of cut flowers. Plant Growth Regulat. 16:93-97.

Wang, Y.T. and J.R. Dunlap. 1990. Leaf abscission in Radermachera sinica in response to ethylene and silver thiosulfate. HortScience 25:233.

Woltering, E.J. 1986. Sensitivity of various foliage and flowering potted plants to ethylene. Acta Hort. 181:489-492.

Woltering, E.J. 1987. Effects of ethylene on ornamental pot plants: A classification. Scientia Hort. 31:283-294.

Wu, M.J., L. Zacarias, and M.S. Reid. 1991. Variation in the senescence of carnation (Dianthus caryophyllus L.) cultivars. II. Comparison of sensitivity to exogenous ethylene and of ethylene binding. Scientia Hort. 48:109-116. 